Original Contribution

\title{
CORRELATION AND PATH ANALYSIS OF INTERACTION BETWEEN GREEN PEA YIELD AND ITS COMPONENTS WITH CROP MANAGEMENT
}

\author{
N. Shaban* \\ Department of Agronomy, Faculty of Agriculture, University of Forestry, Sofia, Bulgaria
}

\begin{abstract}
Determinations of interaction between yield its components and foliar mixed application of Lactofol ${ }^{\circledR}$ with insecticides and herbicides. The path-coefficient analysis is very important statistical technique that can be used to quantify the interrelationship of different yield components. It was applied to study the interaction of applied agronomic activities on productivity of mid-early Bulgarian garden peas Pisum sativum cv. Promethei seeking to minimize pesticide use and to maintain sustainable quality and quantity of yield, and to prevent underground water pollution caused by using Dual 930EK/930g/l-s (metachloras) minimized herbicide doses from vegetative herbicide Basagran-200g/l (Bentazon) and Fusillade-200g/l (Fluasifop-P-Butil). Data was collected from long years trials on plants treated with different combinations of foliar suspension fertilizer Lactofol ${ }^{\mathbb{Q}}$ with insecticides and herbicides. Results showed that grain yield (0.997), dry matter of the grain (0.996), Chlorophyll "a" (0.993), Zn (0.992), N (0.991), grain/whole pod ratio (0.984), total nitrogen $(0.982), \mathrm{K}(0.975)$, weight of 50 grains $(0.973)$ fresh weight of 50 beans $(0.962)$, fertile pollen $(0.961)$, plant density/ $\mathrm{m}^{2}(0,873)$, the length of beans $(0.871)$, sterile pollen $(0.837)$ had positive impact on yield. Dry matter, grain yield, dry matter of grains, chla, $\mathrm{N}$, weight of 50 pods, fertile pollen, and plant density $/ \mathrm{m}^{2}$ showed positive direct and indirect effects on yield. Other factors such as sugars $(0.797)$, chlorophyll "b" (0.739), and starch $(0.620)$ had an indirect effect on total yield. Grain yield should be given prior attention in field pea improvement programmers due to its major influence on yield. This research gave valuable information about which steps of agro techniques needs more attention to enhance best quality and quantity of sustainable yield.
\end{abstract}

Key words: Correlation; path-coefficient, garden peas, growth, yield.

\section{INTRODUCTION}

Garden peas are highly valued crops worldwide with multiple uses in food consumption. Grain peas are highly nutritious and are rich in protein (27\%), complex carbohydrates $(42.65 \%)$, vitamins, minerals, dietary fibers and antioxidant compounds (1).Yields and production areas have increased during the last years (2). The total harvested area in Bulgaria is of 882 ha, with a total production of 17358 tons (3). One of the best methods to ensure the high quantity and quality of garden peas is to apply new agro technical solutions while protecting ecosystems from pollution (4). The correlation

*Correspondence to: Nidal SHABAN, Department of Agronomy, Faculty of Agriculture, University of Forestry in Sofia, St "kliment ohridski”, 1797Sofia, Bulgaria, e-mail: shaban.nidal@gmail.com coefficient value ranges from -1.0 to +1.0 . Where the value of -1.0 indicates a complete negative relationship, while the value of +1.00 indicates an ideal positive relationship. While the value 0.00 represents a lack of correlation. The grain yield of peas is a complex character and is the product of several contributing factors affecting yield directly or indirectly. Correlation analysis provides information about the association of plant characters and therefore, leads to a directional model for yield prediction. Path coefficient analysis quantifies the interrelationships between different components in their direct and indirect effects on grain yield (5).

In agricultural production, higher interaction between different parameters and the presence of contrasting developments in their effects on the yield is often not possible to separate the 
effects with significant impact on mathematical modeling- water efficiency and its contribution to the yield (6). Application of Path- analysis in determining the independent variables in the construction of production function allows to identify the most significant of them and the nature of their interaction in forming the productivity of individual plants (7-9). Pathanalysis has advantages in terms of assessment of the factors and influences the prognostic results than classical statistical methods. Production function analysis has advantages in the yield of agricultural crops not only because it allows establishing relationships but is also valued and key indicators such as average and marginal efficiency coefficient of elasticity and production rate alternative variables (10). It explores the dependence of the rate of change in volume of the factors forming yield (11). For instance, on peas, it was found that plant height showed positive direct effect on seed yield and that No. of pods/plant is a highly reliable component for yield indications (12-17). In the same trend, the correlation between seed yield with plant height, number of pods/ plant and biological yield/plant and number of seeds/pod was highly significant and positive(18). Correlation studies showed that the grain yield was positive correlated with plant height, No. of pods/plant and number of seeds/pod.

The present study was conducted in order to investigate the interrelationship of yield components and applied new techniques (mixed foliar fertilizer with decreased pesticide doses) and their contribution to yield of peas.

\section{MATERIAL AND METHODS}

Data was collected through long years field trial with mid-early garden peas of the cultivar Promethei. Seeds were sown with the help of a trible with a distance of $30 \mathrm{~cm}$ between rows and $5 \mathrm{~cm}$ between plants. The experimental design adopted was RCBD (Randomized Complete Block Design) with four replications. All agronomic practices were kept uniform. Plants were treated with different combinations of foliar suspensions fertilizer Lactofol ${ }^{\circledR}$ with insecticides and herbicides. At maturity, ten monitored plants were chosen from each replication for measuring the number of pods, number of grains per pods, grain weight per pod $(\mathrm{g})$, weight of 50 pods $(\mathrm{g})$ and grain yield per plant $(\mathrm{g})$. Moreover, plant physiology was analyzed through three measurements of photosynthetic and transpiration intensity, and through analysis of photosynthetic pigments (chla, chlb and carotenoids). The chemical composition of plants was evaluated by testing the micro and macronutrients contents. Weed density was monitored and recorded as well during the consecutive experimental years.

Correlation coefficients were calculated for fixing the degree of association of the different investigated parameters and pea yield as well as among themselves. Correlations were calculated based on (19) and path coefficient analysis was carried out as suggested by $(20,19,21,22)$. The analysis was done using AMOS Ver. 18 Software.

\section{RESULTS AND DISCUSSION}

Correlation is the degree of closeness of relations between two or more characters. The correlation coefficient is the basic benchmark for determining the closeness of relationships between characters, whether each character observed has a close relationship or not. Correlation analysis can provide additional information about the presence of certain characters, which are important components that affect a character. (23)

The closeness of the relationship between characters is shown by the correlation value (r), which is between -1.00 and +1.00 and the value of 0.00 indicated there was no relationship between the two variables. This means that the value of -1.00 and so on indicates a negative correlation, and the value of +1.00 indicates a positive correlation, while the value of 0.00 indicates no correlation between the observed characteristics (24). (25) confirmed that if the correlation approaches 1.00 , it means that the relationship between the characteristics is closer.

Results of correlations between the yield of green peas and each of the studied parameters of direct and indirect Path-factor are given in Table 1. The model of research indicated that the total impact of the studied indications on the yield of peas was variant and ranged from strongly positive to strongly negative. The strongest overall positive impact on the yield of peas was exerted by the grain yield $(5.4 \%)$ and the absolute dry matter content in whole pods (ACB*) $(5.4 \%)$ followed by dry matter of the grains (5.3\%), Chla $(5.3 \%)$, total $\mathrm{Zn}(5.3 \%)$, grn/pod rate (5.2\%), total nitrogen $(5.2 \%)$, total $\mathrm{K}(5.1 \%)$, weight of 50 grains $(5.1 \%)$, weight 50 pods $(5 \%)$, pollen fertility $(5 \%)$, ACB B in grain $(5 \%)$, plants/ $\mathrm{m}^{2}$ $(4.1 \%)$, length of pods $(4.1 \%)$, pollen sterility $(3.8 \%)$ and transpiration at third measurement E3 (3.6\%). A lower significant effect on yield was observed for the parameters sugar content (3.4\%), Chlb (2.9\%), E2 (2.9\%), disorder post first treatment $(2.6 \%)$ and starch content $(2.1 \%)$. Finally, yield was also influenced by other factors $(2.9 \%)$ 
SHABANN.

Table 1. Partial function of studied parameters on yield structure of green peas.

\begin{tabular}{|c|c|c|c|c|c|}
\hline \multicolumn{6}{|c|}{ General variability of yield } \\
\hline \multicolumn{6}{|c|}{ Partial function of studied parameters $97.1 \%$. from: } \\
\hline No & & 100.0 & No & & 100.0 \\
\hline 1 & Plants/m2 & 4.1 & 12 & Weight of 50 grains & 5.1 \\
\hline 2 & Disorders post first treatment & 2.6 & 13 & Grain /pod rate & 5.2 \\
\hline 3 & $\begin{array}{l}\text { Absolute dry matter in whole } \\
\text { pods ACB* }\end{array}$ & 5.4 & 14 & Absolute dry matter in grains ACB B & 5.0 \\
\hline 4 & Sugars & 3.4 & 15 & Pods length & 4.1 \\
\hline 5 & Total nitrogen & 5.2 & 16 & Grain yield & 5.4 \\
\hline 6 & Starch & 2.1 & 17 & Pollen fertility & 5.0 \\
\hline 7 & Dry matter/ grain & 5.3 & 18 & Pollen sterility & 3.8 \\
\hline 8 & $\mathrm{~N}$ & 5.3 & 19 & E2- Transpiration at second measurement & 2.9 \\
\hline 9 & $\mathrm{~K}$ & 5.1 & 20 & E3 Transpiration at third measurement & 3.6 \\
\hline 10 & $\mathrm{Zn}$ & 5.3 & 21 & Chla & 5.3 \\
\hline 11 & Weight of 50 pods & 5.0 & 22 & Chlb & 2.9 \\
\hline & \multicolumn{4}{|l|}{ Other factors: $2.9 \%$} & \\
\hline
\end{tabular}

Correlations in Figure 1 reflected a moderate positive correlation between pollen fertility and weed density (0.4) as well as with weeds weight (0.58). On the other hand, total $\mathrm{Ca}$ was negatively correlated with those two parameters $(-0.57$ and -0.55 respectively).The correlation between the photosynthetic intensity, transpiration intensity, pollen viability, pods yield and grain yield. In specific, pollen fertility has a moderately direct positive influence on grain yield (0.5), and a moderately negative influence on pods yield (-0.38). Additionally, this parameter was negatively correlated with photosynthetic intensity (A1: -0.2 and A2: -0.35 ). On the contrary, pollen sterility was positively correlated to photosynthetic intensity (A1: 0.39 and A2: 0.45).

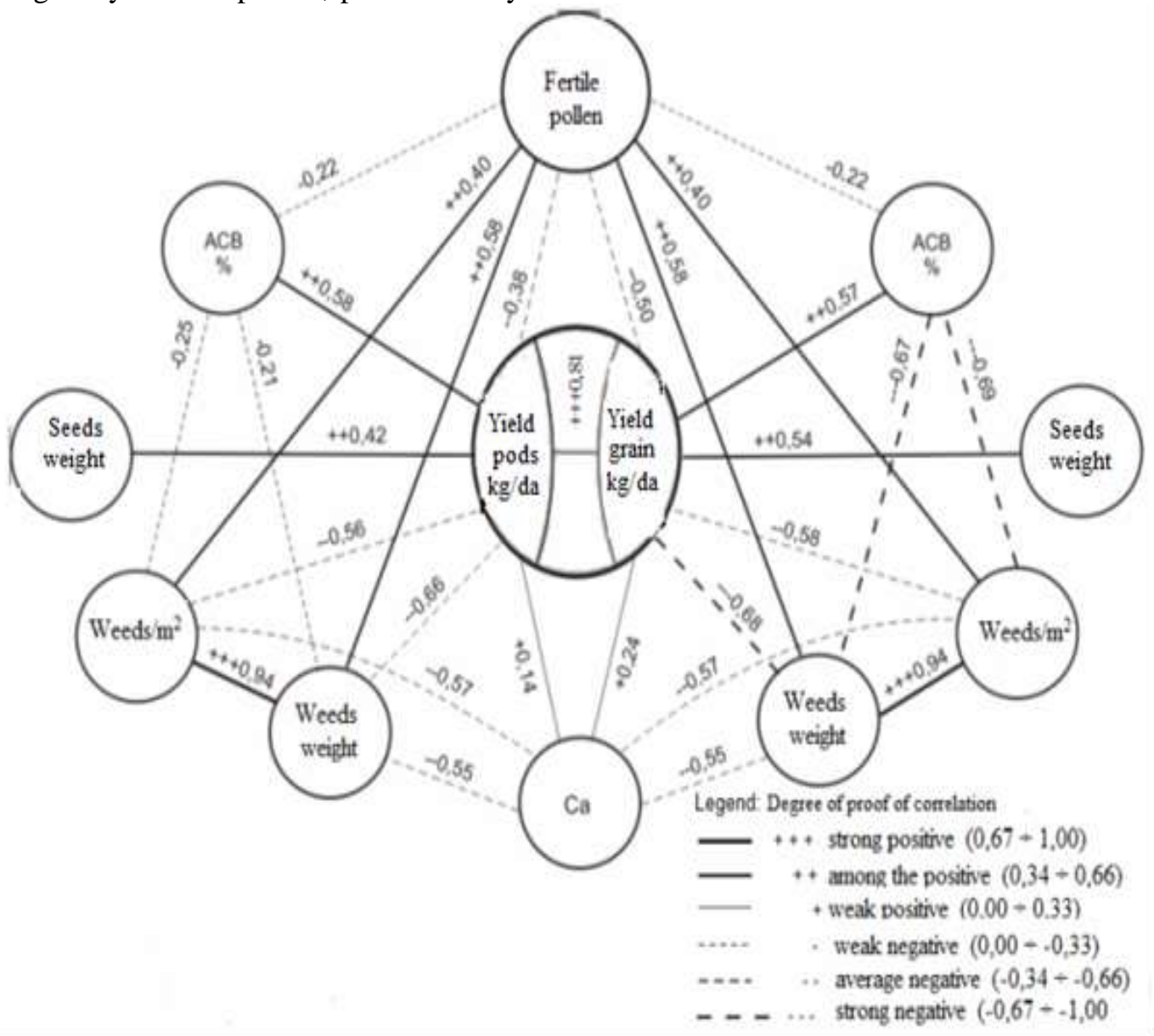

Figure 1. Impacts of treatment with Lactofol ${ }^{\circledR}$ and pesticides on correlation coefficients and between yield and peas parameters 
Results in Figure 2 illustrated the existing correlations between physiological parameters and yield. When considering the physiological activity of plants it seemed that photosynthetic pigments (chla, chlb and carotenoids) were positively correlated with transpiration rate and with photosynthetic intensity with some exceptions: chla was negatively correlated with
A2 (-0.32) and chl b was negatively correlated with E3 (-0.44). In general, correlations between photosynthetic pigments formation with transpiration intensity were stronger than those with photosynthetic intensity. For instance, the correlation coefficient of chla, chlb and carotenoids $(a+b+c)$ with $E 1$ was +0.69 while with $\mathrm{A} 1$ it was of +0.11 .

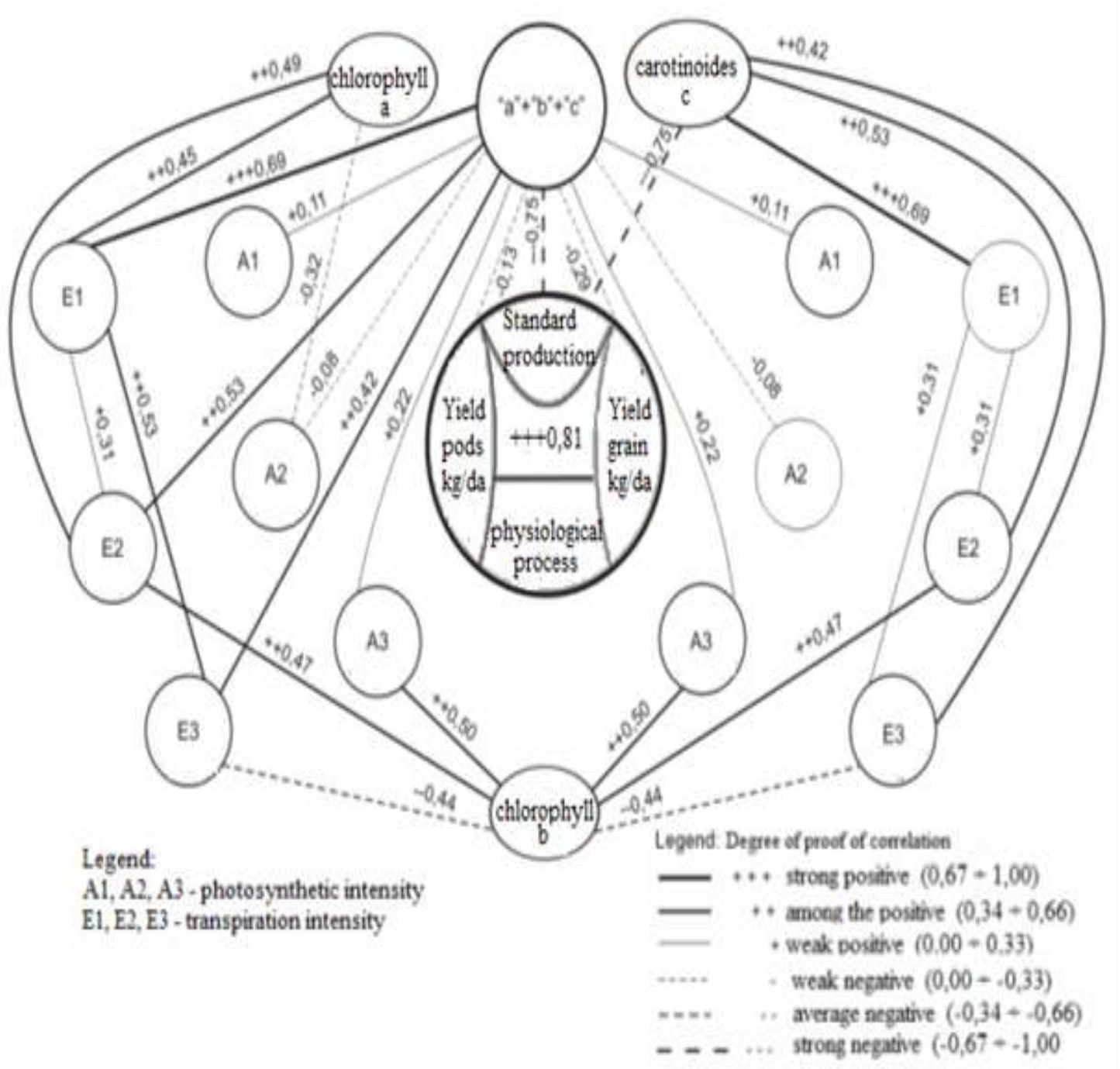

Figure 2. Impacts of treatment with Lactofol ${ }^{\circledR}$ and pesticides on correlation coefficients and between yield and plastid pigments content and photosynthetic and transpiration intensity of peas plants

Moreover, the parameters ACB (\%) had a strong positive influence on grain yield (0.62) and pods yield (0.58). Total $\mathrm{Cu}$ content had a strong positive influence on grain yield $(0.51)$ and a weak positive influence on pods yield (0.27). In addition, total $\mathrm{N}$ and total Ca content had a weak positive influence on yield, while total $\mathrm{P}$ content showed an indirect positive influence (Figure 3).

Results in the figure 4 showed that in general, pods characteristics such as the number of grains per pod, weight of 50 grains, and weight of 50 pods had always a strong direct positive influence on each other as well as on pods yield and grain yield consequently on productivity. For example, the weight of 50 seeds was positively correlated with grain yield and pods yields with 0.54 and 0.42 respectively. In addition, the figure 4 illustrated the direct and indirect effects of different chemical parameters ( $\mathrm{Fe}, \mathrm{Mn}, \mathrm{Cu}$ and $\mathrm{Zn})$ on all the previously cited pods characteristics as well as on pods length. For 
instance, $\mathrm{Zn}, \mathrm{Fe}$ and $\mathrm{Mn}$ had a moderate positive direct influence on number of grains per pods with respective correlation coefficients of $0.35,0.43$ and 0.38 . On the other hand, $\mathrm{Mn}$ influenced directly and negatively the pods length $(-0.38)$.

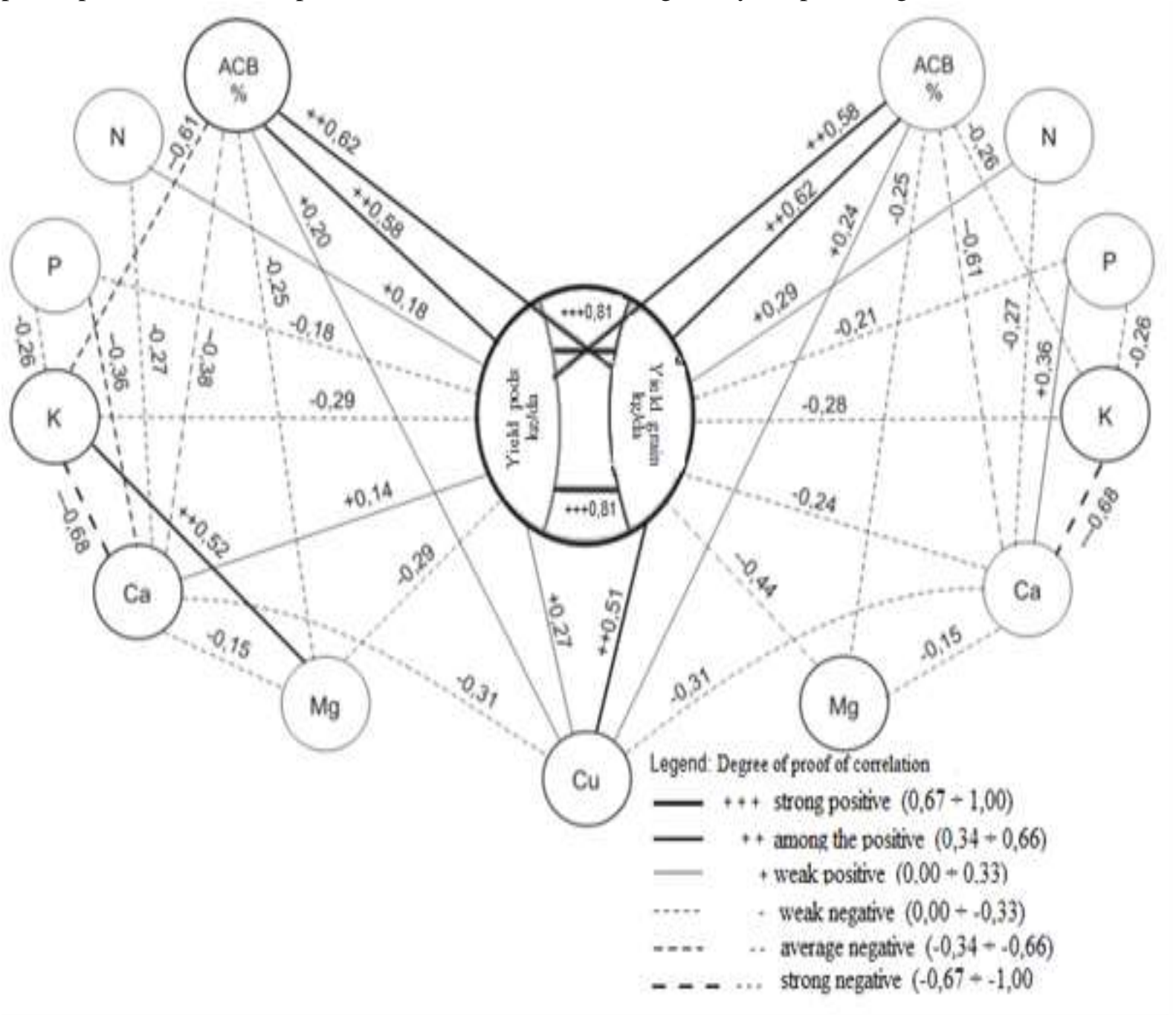

Figure 3. Impacts of treatment with Lactofol ${ }^{\circledR}$ and pesticides on correlation coefficients between yield and biological values of peas

Grain yield should be given prior attention in field pea improvement programmers because of its major influence on yield. Those results came in conformity with those of earlier studies where a positive association of seed weight and grain yield / plant was reported $(26-29,15,16)$. Also, it was found previously by (15-16) that No. of pods / plant exerted the highest direct effect on seed yield in field pea. This indicates that No. of pods / plant is a highly reliable component on yield. It was also found in the study of (30) that there is a significant positive correlation between grains yields with, number of pods / plant and 100 seed weight in pea. A number of pods / plant were also reported to be positive correlated in pea.
Direct and indirect effect of different traits on seeds pods\% of peas at genotypic level is presented in Figure 1 Number of seeds weight of 50 pods pod had exerted the highest positive direct effect on green pod yield per plant which led to positive and significant correlation of this trait with grain pod yield per plant. The second maximum positive direct effect was exerted by a single green pod weight. These traits ultimately affected green pod yield mainly with their substantial positive direct effects. The other positive direct effect was exerted by dry matter contents with the yield pods. Similarly, positive direct effects of green pod number per plant and single green pod weight on green pod yield per plant reported. (31-32) 


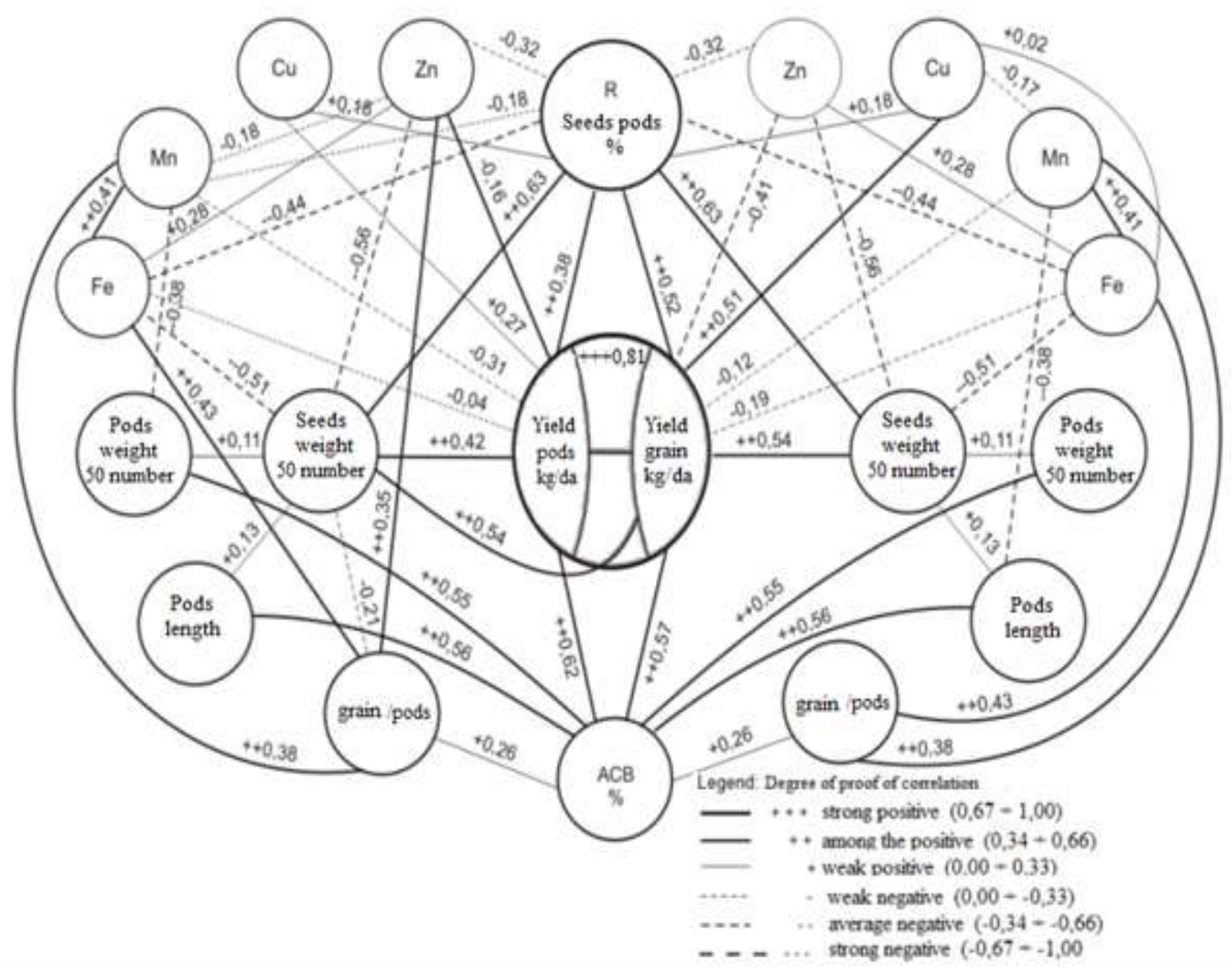

Figure 4. Impacts of treatment with Lactofol ${ }^{\circledR}$ and pesticides on correlation coefficients between yield and productivity parameters of peas

\section{CONCLUSIONS}

The application of foliar suspension fertilizer Lactofol $^{\circledR}$ combined with insecticides and herbicides has induced different effects of the studied parameters (morphological, physiological and reproductive) on the yield. In general, this type of treatment has amplified the effects of macro and micro-nutrients in plants, dry matter accumulation and those of pods characteristics on plant yields. Moreover, crop performance was more correlated to the transpiration intensity and less to the photosynthetic intensity while yields were the most affected by grain and pods productions. It seemed that the use of Lactofol had an indirect negative effect on photosynthetic pigments however it caused a direct beneficial impact on the quantity and quality of the produce. Also, the negative correlation that was observed between weed incidence and yields could lead to the assumption that Lactofol might help controlling weeds while maintaining high quality yields. Also, the impact of posttreatment disorders on yields was lowered since results clearly demonstrated a low correlation between this parameter and yields.
Lactofol could be used as a potential foliar fertilizer in application of GAP (Good Agricultural Practices) as a new way in order to reduce the excessive random application of chemicals, consequently to help sustaining the ecosystem by preventing underground water pollution.

\section{REFERENCES}

1. Urbano G., Aranda P. and Gomez-Villalva E.. Nutritional evaluation of pea (Pisum sativum L.) protein diets after mild hydrothermal treatment and with and without added phytase. Journal of Agricultural and Food Chemistry, 51: 2415-2420. 2003.

2. Shaban N., Bistrechanov S., Moscova T., Eman K., Ivanka M., Miroslav T. and Pavel B.Vegetable production of traditional crops. Sofia Published in University of Forestry Sofia ISBN:978-954-332-116-2.2014

3. Food and Agriculture Organization of the United Nations. FAOSTAT Database. 2014.FAO. Retrieved September 8, 2017, from:

http://www.fao.org/faostat/en/\#data/QC 
4. Shaban N. Agrobiological complex assessment of mixed application of pesticides with foliar fertilizer on growth and development of Tomato, French bean and peas. Doctor of Sciences Thesis Sofia 2007. (2007). University of Forestry Sofia

5. Aashfaq M., Khan A.S. and Zulfiqar A. .Association of morphological traits with grain yield in wheat. Int. J. Agri. Biol., 5: 262-264. 2003.

6. Chowdhry M.A., M. Ali, G.M. Subhani and Khaliq I.. Path coefficients analysis for water use efficiency, evapotranspiration efficiency and some yield related traits in wheat at different microenvironments. Environ. Ecol., 9: 906-10. 2000.

7. Jedynski S. Heritability and path coefficient analysis of yield components in spring wheat. International journal of agriculture \& biology. 1560-8530/2004/06-1-138142. 2001. http://www.ijab.org.

8. Kashif $M$. and Khaliq I. Heritability, Correlation and Path Coefficient Analysis for Some Metric Traits in Wheat. INTERNATIONAL JOURNAL OF AGRICULTURE \& BIOLOGY 15608530/2004/06-1-138-142.2004 http://www.ijab.org

9. Narwal, N.K., P.K. Verma and M.S. Narwal,. Genetic variability, correlation and path coefficient analysis in bread wheat in two climatic zones of Haryana. Agri. Sci. Digest Karnal, 19: 73-6.1999

10.Nayeem K.A. and Baig K.S. Correlation studies in durum wheat. J. Res. Angrau., 31: 116-21. 2003.

11.Steel, R.G.D and J.H. Torrie, Principles and Procedures of Statistics: A Biometrical Approach, 2nd ed., McGraw Hill Book Co., New York 1984.

12.Tiwari, S.K, H.L. Singh, R. Kumar, H.K. Nigam and Singh, A.P. A postmortem of selection parameters in pea ( Pisum sativum L. ). Res. Crops, 2:237-242. 2001.

13.Singh S.K. and Srivastava S.B.L. Comparision of direct and indirect effects of yield traits on yield in tall and dwarf genotypes of pea ( Pisum sativum L. ). Indian Genet. Resour, 14: 201-202. 2001.

14.Gul.I,M.Sumerli,B.Tuba Bicer and Yilmaz Y.Heritability and correlation studies in Pea (Pisum arvense L.)Lines Asian journal of Plant Sciences 4(2):154-158,2005.

15.Arya S., B.P.S. Malik R. Kumar and Dhrai R. Variability, correlation and path analysis in field pea ( Pisum sativum L.). J. Res.
Harayana Agric. Univ. 34:149-153. 2004

16.Singh J.D. and Singh. I.P. Studies on correlation and path analysis in field pea ( Pisum sativum L. ). Natl. J. Plant Improve, 7:59-60. 2005

17.Singh J.D. and Singh I.P.. Genetic variability, heritability, expected genetic advance and character association in field pea ( Pisum sativum L.). Legume Res, 29:65-67. 2006

18.Ceyhan E. and Avci M.A. Combining Ability and Heterosis for Grain Yield and Some Yield Components in pea (Pisum sativum L.). Pakistan Journal of Biological Sciences. 8(10): 1447-1452. 2005.

19.Singh R. K., and Chaudhary B. D.Biometrical Methods in Quantitve Genetic Analysis. Rev.ed, pp318, Kalyani publishers, Ludhiana, New Dlhi. India. . 1985.

20.Dewey D. R and Lu K. M. Correlation and path coefficient analysis of components of crested wheat grass seed production. Agronomy J, 51:515-518. 1959

21.Soomro Z. A. Estimation of Gene Action and Selection Parameters in Quantitative and Qualitative Traits of Gossypium hirsutum L, Ph.D. Thesis , Sindh Agriculture University, Through Department of Plant Breeding and Genetics, Faculty of Crop Production, Tandojam.2010.

22.Arbuckle, J. L. Amos 18 user's guide. Chicago, IL: Amos Development Corporation. 2009

23.Hafsah S., Firdaus F..Correlation between Qualitative Characteristics and Genotype Resistance of Local and Introduced Pepper Varieties Against Anthracnose Disease. Journal of Tropical Horticulture Vol 3, No 1 (2020)pp43-48. (2020)

24.Shaban, N.Analysis of the correlation and regression coefficients of the interaction between yield and some parameters of snap beans plants. Trakia Journal of Sciences, 3(6), 27-31. .2005

25.Hapsari, R. T., \& Adie, M. M. Pendugaan parameter genetik dan hubungan antar komponen hasil kedelai. Jurnal Penelitian Pertanian Tanaman Pangan, 29(1), 18-23. 2010

26. Mahanta I.C, N. Senapati, K. Samal and Dhal A. Genetic variability performance, character association and coheritability in field pea ( Pisum sativum L. ). Indian J. Agric. Sci., 24:92-96. 2001 
27.Singh V. and Singh S.P. Vaiability and correlation studies in pea ( Pisum sativum L. ). Ann. Agri. Bio Res, 4:87-91.1999

28.Gul I, M. Sumerli, B.T. Bicer and Yilmaz Y.Heritability and correlation studies in pea( Pisum arvense L. ) Lines. Asian J. Plant Sci, 4:154-158. 2005

29.Patel P.J., N.H. Patel, B.H. Prajapati , S.B.S. Tikka and Patel. P.T. Correlation and path analysis in field pea. Ind. J. Pulses Res. 19:109-110. 2006

30. Sarawat P, F.L. Stoddard, D.R. Marshall and Ali S.M.. Heterosis for yield and related characters in pea. Euphytica. 80:3948. 1994

31.Alemu Y., S. Alamirew , Dessalegn.L. Correlation and Path Analysis of Green Pod Yield and Its Components in Snap Bean (Phaseolus Vulgaris L.) Genotypes. International Journal of Research in Agriculture and Forestry Volume 4, Issue 1, January 2017, PP 30-36 2017

32. Smitha. Divergence and stability studies in french bean (Phaseolus vulgaris L.). MSC Thesis presented to The University of Agricultural Sciences, 2005. 